\title{
I Pledge Allegiance
}

\author{
Eugenia Webb-Damron \\ Marshall University \\ 100 Angus E Peyton Dr \\ South Charleston, WV 25503 \\ United States
}

\begin{abstract}
Civics, civility, and citizenship might be what many of us would consider the fabric of society. But how do we define these and what values and virtues do we still hold as truths? What do these questions mean to students in the United States? What do they mean to students around the world? This paper compares how civics, civility, and citizenship are taught and manifest themselves in the United States to how the author saw civics, civility, and citizenship taught and displayed in Mabarumba, Guyana; South America.
\end{abstract}

Keywords: Civics, civility, citizenship

\section{Introduction:}

Education makes a people easy to lead, but difficult to drive; easy to govern, but impossible to enslave."-Henry Peter Brougham

Civics, civility, and citizenship might be what many of us would consider the fabric of society. But how do we define these and what values and virtues do we still hold as truths? What do these questions mean to students in the United States? What do they mean to students around the world? Civics as taught in our curriculum emphasizes building communities, establishing rules, choices and voices, leadership, rights and responsibilities, compromise, and activism (Brasof\& Spector, 2016). Civility, is how citizens treat each other. It incorporates the concepts of majority rule with tolerance, compromise, individualism, and a respect for minority rights. Civility is manners, politeness, and proper behavior (Moore, 2012). Citizenship, brings to mind ideals of the rights and responsibilities we have as citizens of the United States. We demand freedom of speech, we argue over gun control, but we all don't vote even though it is our right. Is citizenship changing, are we now global citizens who need to think about the world we live in rather than just the nation we claim as ours? What does that look like?

The fluidity of our borders increases each day, migration, free trade, the internet, social media, and national agreements such as the Declaration of Human Rights or the Paris Climate Agreement all shape the way in which our students see and interact with the world (Tichnor-Wagner, 2017). While our students become more globally aware and invested we also notice a decline in the civility and civic ethics that are integral to becoming a global citizen. In The Vanishing American Adult, Sasse (2017) avers that along with the disappearing adult, our system of civics and citizenship is increasingly dissipating as well. Gregg (1998) avers that civility is hard to judge; but participation in civic activities, such as attending community meetings, volunteering on community projects, or even reading the newspaper are good indicators of a society's civic virtue. Levine (2010), laments that these indexes are fading.

Moore (2012) ascertains that schools need to teach civic virtues through the rooted notion that all people are created equal and deserve respect. In an already saturated curriculum teachers in the United States are charged with Peace Builders, Positive Behavior Support Systems, Conflict Resolution, or a plethora of other civility teaching programs. These programs teach students how to behave respectfully and responsibly mirror the respect we have for constitutional order and fellow citizens (Gregg, 1998). Our question then must be, are these programs working? Positive Adolescence Choices Training (PACT), Promoting Alternative Thinking Strategies (PATHS), Peace Builders, Peer Mediation in Schools Program, Positive Behavior Intervention Support (PBIS), and a multitude of other programs are touted in the United States as the panacea for changing behaviors and promoting civility (Gregg, 1998). These efforts and many others make us feel like we are doing the right things; but; we find increasing instances of school violence, a rise in discipline referrals, and a decline in the civility we see among children and adults.

Evidence suggests that student incivility is increasing; we see slander, ridicule, demonizing of certain groups of people, and of course violence in schools. Moore (2012) is so bold to say that civility is a moral imperative, and that in order for teachers to be able to teach civility they must first establish a positive climate and culture of acceptance. Teachers have to emulate the behaviors they expect to see and they have to establish the rules of decorum that allow civility to 
flourish even when people disagree. In her work with school bullies, Willard (2017), avers that change in students requires emulating and teaching being kind and respectful. Students don't know how to behave until we teach them.

The inculcation of polite social norms not only allows students to learn from each other; but it promulgates the ideals of equality and rights with responsibilities. Moore, (2012) reiterates that the teaching of diversity often plays a role in incivility; because then citizens do not feel a common national identity.

It is this idea that causes Moore (2012) to insist that civility be taught in schools, and that the emulation of civic virtues helps establish the civic mindedness for which we strive. Tichnor-Wagner (2017) reiterates this with his plea for inspiring global citizens, in which students experience a sense of belonging, with shared duties and morals, while gaining empathy, and respect for diversity.

Moore, (2012) offers many suggestions for creating a culture of acceptance where civic virtues can not only be taught, but be watched. He avows that teachers must be excellent role models; from the way they dress to the verbiage they use to gain respect. Moore demands that teachers demand civility in all interactions. He cautions teachers about letting their political views get in the way of teaching. As in any class behavior system, students have to know what to expect, why, and what the consequences are. Respect and civility must be taught; students have to know what you mean by those words. Tichner-Wagoner (2017) affirms that a more peaceful world will take place through actions of respect and responsibility.

The statistics and policy briefs that tell us what to do are endless; the programs and curriculum sold to our schools in unceasing. In schools where programs such as the Rendell Center for Civics and Civic Engagement (Brasof\& Spector 2016) or The Positive Adolescents Choices Training (PACT) are touted as making a difference we find hope. We are teaching our students about governance, and we are teaching diversity at many levels. This may or may not be enough; but what are they doing in other counties? What are the results and findings? How do we compare?

\section{Guyana, South America}

A few years after the United States desegregated schools, the education system in Guyana was recognized as one of the best in the English speaking Caribbean. Societal value on education, the right to an education, and compulsory education all stem from the British colonial influence and control as early as 1876 (Critchlow, 2003). In a country which is considered to be third world, and poverty stricken; the education system seems to shine. Curriculum reform and societal expectations and influence appear to create an atmosphere of civics and civility within the schools. Shridath Ramphal, Former Secretary General of the Commonwealth contends that schools in the Commonwealth are expected to promote democracy and civic responsibility, they are to strengthen family cohesion, end inequality for women, and prevent crime; a list that sounds much like the one teachers in the United States tout. Ramphal complains that education not only shapes society, but that it also mirrors it. Schools reflect the disrespect for authority, competition, individualism, and even violence seen in society; and thus the hint of the same decay we see in the United States (Ramphal, 2009).

Ramphal (2009) ascertains that the shrinking world makes global understanding more critical. Just like in the United States, the opening of borders requires acceptance, cultural awareness, and other acts of civility. Guyana, and other countries in the Commonwealth find a greater need for democratic structures than they have in the past. Developing countries also have increased expectations as global travel and internet capabilities expand (Jindal, Mehta, Soni, Doyle, and Patel, 2016).

In his article Violence, Past and Present: "Mati" and Non-mati" People, Halstead, (2008) describes violence as a pendulum that swings between coexistence and active violence. This violence is blamed on politicians not race, and the coexistence that comes about isn't taught in the curriculum; it is the wave of societal norms. Halstead blames the violence on cultural distinctiveness; averring that they insist on being different. In the United States we claim to teach acceptance of this difference and laud our efforts to let cultures be expressed.

Programs that teach social competence and civility in schools, such as Schools Teaching Options for Peace (STOP), Responding in Peaceful Positive Ways (RIPP), and The Second Step Curriculum to name a few, (AEL, 1198) are not taught in Guyana. In fact, Wilson, Wilson, and Fox (2002) avow that societal norms and social contexts are taught at home. They believe that society sets the rules for parents to administer, and for children to function within. It is in this context that schools function and discipline is primarily left to parents. Ramphal (2009) reiterated that education could ameliorate economic disparity and lagging social development; but stated that it could not be the panacea for what ailed the Commonwealth. 
It appears that in developing countries such as Guyana the people believe that the educational system is responsible for teaching academics such as reading, writing, arithmetic, science, and in some instances conservatism. Overwhelmingly, the educational system is not expected to, nor asked to deliver a curriculum which teaches children how to behave. In an interview with Nigel Richards, Regional Education Officer Region1, I asked what he thought made the children so well behaved in school, even when teachers were not supervising them or they were not engaged. He said, parents and society. This is a region in which if a child misbehaves someone is going to tell his parents, and the parents are going to discipline the child. When pressed for more information he said children were taught respect; they knew they had to answer to their elders. In an area as poor as this, where everyone relies on everyone for food, transportation, and help, children are taught to treat others well.

As an observer I could understand this; but wondered if the political context might have more control than considered. The schools were rigid, formal, controlled in a way that we don't see in the United States. There was often chaos, and students were not engaged or on task as is expected in the United States; but this did not happen during transitions or free time. The classrooms themselves were more lax. Students arrived at school almost whimsically, some walking, some riding the bus; but all in clean uniforms without a hair out of place. They laughed and played until the first bell at which time they immediately washed their feet with water collected from the rain. At the sound of the second bell they lined up; a process they had obviously practiced often. At this time they formally said the Pledge to Guyana; sang the national anthem, said the school pledge, sang the school song, and then said a prayer. This process was formal and if students were not engaged would often be started anew until everyone was participating. This entire morning routine often felt like scripted government control to this outsider, but to the educators in the building it was a routine they felt like students should know, respect was demanded.

This respect did not seem to come from fear, it came from expectation and emulation; students and adults spoke to every person they encountered. Much like Nigel said, kindness and politeness were expected. The bus driver greeted us each morning with Hi Miss, as did every student and person on the street. This act of civility was heart-warming. Once when walking the last mile of the trip to school because the roads were too bad to traverse, students ran to me with their umbrella. Not only was it polite to help others, they genuinely wanted to do so.

\section{Countries all over the World}

Countries all over the world are experiencing the changes that come with globalization. In 1492 Columbus declared the world was round, in 2002 Friedman heralded that it was indeed flat. Friedman lists ten things that flattened the world; and these world flatteners have created a whole new world for our children. A world in which civics, civility, and citizenship are ever changing. In 1998, David Blunkett, then Secretary of State for Education and Employment in England created an advisory group, Education for Citizenship and the Teaching Democracy to which he charged curriculum reform such as: school and community relations, citizenship behaviors in a global context, and individual participation in politics and society (Kerr, 1999). In South Africa, Stellenbosch University is calling for social transformation and community engagement (Costandius, Rosochacki, le Roux, 2014). Finkel and Ernst (2005) question the effectiveness and reliability of civic education programs; yet admit they are abundant in Post-Apartheid South Africa. Moon, (2013) asserts that South Korea textbooks incorporate Wester beliefs about diversity and multiculturalism; this citizenship education comes as response to migration and world changes.

The question still remains, are the programs we taut as civic education, the responsibilities we feel at citizens, and our standards of civility enough? Are we meeting the needs of a world with no borders and a people of such diversity?

\section{References}

Brasof, M., \& Spector, A. (2016). Teach students about civics through schoolwide governance. Phi Delta Kappan, 97(7), 63-68. doi:10.1177/0031721716641652

Cossa, M. (2006). How Rude! Using Socio-drama in the Investigation of Bullying and Harassing Behavior and in Teaching Civility in Educational Communities. Journal of Group Psychotherapy, Psychodrama \& Sociometry 58(4), 182-194.

Critchlow, D. (2003). Advancement of Education in Guyana. UN Chronicle, 40(3), 47.

Friedman, T. (2005). The world is flat: A brief history of the twenty-first century. New York: Farrar, Straus and Giroux.

Halstead, N. (2008). Violence, Past and Present: "Mati" and "Non-mati" People. History \& Anthropology, 19(2), 115129. doi:10.1080/02757200802320918

Howe, D. (2008). Violence stalks the Caribbean. New Statesman, 137(4885), 2. Retrieved from 
http://muezproxy.marshall.edu:2059/login.aspx?direct=true\&db=aph\&AN=300164

$71 \&$ site $=$ ehost-live

Jindal, R., Mehta, K., Soni, R., Doyle, A., \& Patel, T. (2016). Diabetes, hypertension, sanitation, and health education by high school students in Guyana, South

America. Indian Journal of Nephrology, 26(3), 192-198. Retrieved from https://muezproxy.marshall.edu:2390/10.4103/0971-4065.161522

Kerr, D. (1999). Changing the Political Culture: the Advisory Group on Education for Citizenship and the Teaching of Democracy in Schools. Oxford Review of Education, 25(1/2), 275-284. doi:10.1080/030549899104251

Levine, P. (2010). Teaching and learning civility. New Directions for Higher Education, 2010(152), 11-17. doi:10.1002/he.407

Moore, J. (2012). A Challenge for Social Studies Educators: Increasing Civility in Schools and Society by Modeling Civic Virtues. Social Studies, 103(4), 140-148. doi:10.1080/00377996.2011.596860

Ramphal, S. (2009). Education: Jewel in the Commonwealth's Crown. Round Table, 98(405), 663-678. Retrieved from https://muezproxy.marshall.edu:2390/10.1080/00358530903371379

Sasse, B. (2017). The Vanishing American Adult. Kirkus Media LLC. Retrieved from https://search-proquest-com.marshall.idm.oclc.org/docview/1899862191?pq-origsite=summon

Tichnor-Wagner, A. (2017). Inspiring Global Citizens. Educational Leadership, 75(3), 69-73. Retrieved from http://web.b.ebscohost.com.marshall.idm.oclc.org/ehost/pdfviewer/pdfviewer?vid=1\&sid=d2fd6c9d-0e7c-479a-aa715ace9cee2fa6\%40sessionmgr104

Wilkins, K., Caldarella, P., Crook-Lyon, R., \& Young, K. (2010). The Civil Behavior of

Students: A Survey of School Professionals. Education, 130(4), 540-555.

Willard, N. (2017). Summer of unrest brought teachable moments: Schools must collaborate with students to spread civility. District Administration, 53(10), 62.

Wilson, C., Wilson, L., \& Fox, C. (2002). Structural and Personal Contexts of Discipline Orientations of Guyanese Parents: Theoretic and Empirical Considerations. Journal of Comparative Family Studies, 33(1), 1-13. 